\title{
大気圧誘導熱プラズマを用いた 電力用遮断器消弧媒体の消弧基礎特性の診断
}

\author{
正員 田 中康 規 (金沢大学) \\ 正員作 田.忠裕 (金沢大学)
}

Diagnosis of Arc Quenching Property of $\mathrm{SF}_{6}$ Gas

using Inductively Coupled Thermal Plasma Technique

Yasunori Tanaka, Member, Tadahiro Sakuta, Member (Kanazawa University)

\begin{abstract}
The Ar-SF 6 inductively coupled thermal plasma (ICTP) at atmospheric pressure was successfully generated for different $\mathrm{SF}_{6}$ admixture ratios in order to investigate the quenching effect of $\mathrm{SF}_{6}$ injection on thermal plasma from the viewpoint of elucidating a remarkable interruption ability of $\mathrm{SF}_{6}$. Spectroscopic observation was carried out to measure the radial distributions of the radiation intensity of Ar lines and temperature for the $\mathrm{Ar}-\mathrm{SF}_{6}$ ICTP. It was found that only $0.5 \% \mathrm{SF}_{6}$ injection caused a $1 / 2$ decrease in the radiation intensity and $1000 \mathrm{~K}$ decline in the temperature on the centre axis at $10 \mathrm{~mm}$ below the coil end. A two-dimensinal hydrodynamic model was developed for $\mathrm{Ar}_{-} \mathrm{SF}_{6} \mathrm{ICTP}$ to simulate flow and temperature fields on the assumption of the local thermal equilibrium. The results obtained from the calculation indicated that a little $\mathrm{SF}_{6}$ addition to Ar ICTP decreased high temperature area above $9000 \mathrm{~K}$ drastically. This temperature decaying tendency agreed with the experimental results.
\end{abstract}

キーワード : 高気压，誘導熱プラズマ, $\mathrm{SF}_{6}$ ガス，環境適応型ガス，放射強度，温度

\section{1.まえがき}

大容量電力用遮断器の消弧媒体として仗, 現在 $\mathrm{SF}_{6}$ ガス が主流となっている。この $\mathrm{SF}_{6}$ ガスは極めて安定度の高い化 合物で, $0.1 \mathrm{MPa}, 300 \mathrm{~K}$ 程度の条件下では不活性，不燃， 無臬，無毒の物質であり，その消弧能力は空気の100倍程度 といわれている(1)(2)。しかし， $\mathrm{SF}_{6}$ ガスは，温室効果指標 の GWP(Global Warming Potential) が $\mathrm{CO}_{2}$ の 23900 倍 と非常に大きいため, 1997 年気侯変動枠組み条約第三回 締結国会議COP3において排出削減対象ガスに指定され た ${ }^{(3)}$ このように環境問題が大さくなっていく中で，遮断 器消弧媒体においても，高性能で環境に優しいガスが切望 されている。これまでにも，樣々なガスあるいは $\mathrm{SF}_{6}$ 混合 ガスに対する遮断性能，アーク基礎特性を実験的理論的に 検討した例はある。(4)〜(18) しかしながら，環境負荷を考虑 した新しい概念で, 環境適応型ガスの中から遮断器消弧媒 体を探索した例はほとんどない。今後はこのような概念か らの消弧媒体探索が必要とされる。

これまで消弧媒体の消弧能力を検証する実験室規模の基 礎装置として器壁安定化ア一ク装置などのアーク装置が用 いられてきた (19)。しかし，これらの装置においてはア一
クに電極あるいはノズルなどからの材料混入が避けられな いなどの理由から，ガス自身の消弧効果あるいは材料混入 の影響を基礎実験的に検討するのは極めて困難であった。

筆者らは，消弧媒体プラズマを基礎的に検討する新しい 手法として，「高周波誘導熱ブラズマ(Inductively Coupled Thermal Plasma; ICTP) 装置」を使用することを提案し ている ${ }^{(20)}$ 。高周波誘導ブラズマの特徴として，(1) 無電極 でクリーンなプラズマ空間を生成できる，(2) 再現性がよい， (3) クリーンなプラズマ自身の基礎特性を検討できる，(4) 電極抢よびノズル材料を意四的に混入すれば，それらがブ ラズマに与える影響を検討できる，などがあげられる。こ れまでは，圧力 $200 \operatorname{Torr}(=27 \mathrm{kPa})$ の条件において， $\mathrm{SF}_{6}$ ガス混合の影響を検討した ${ }^{(20)}$ 。しかし，遮断器においては 圧力は数百 $\mathrm{kPa}$ であり，そこで発生するアークプラズマも 熱ブラズマといわれる高気圧，高温，高衝突頻度状態にあ るはずである。そこで本論文では，誘導熱プラズマ発生装 置において，圧力を大気压まで上昇させてクリーンな熱ブ ラズマを点弧し，遮断器消弧媒体が熱プラズマに与える影 響を実験的に検討している。具体的には，電源入力電力 50 $\mathrm{kW}$ ，ト一チ内压力 $0.1 \mathrm{MPa}$ の高出力・高気王の $\mathrm{Ar}$ 誘導熱 プラズマを点弧している。さらに本論文にお゙いては $\mathrm{SF}_{6}$ ガ 


\section{Electrode}

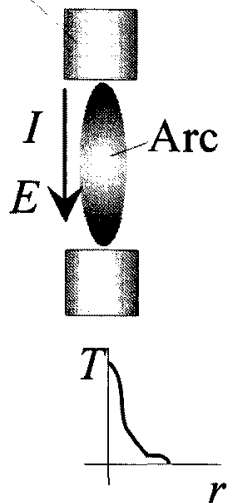

(a) Arc
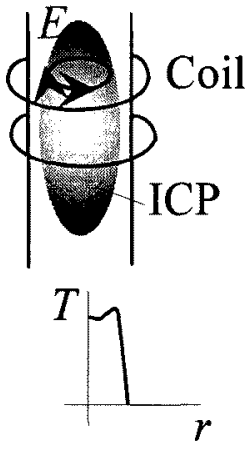

(b) ICP
园1 アークと誘導熱プラズマ

Fig. 1. Arc and ICTP.

スの混合比を $0.0,0.2,0.5,1.0$ および $2.0 \%$ と変化させた 場合についてブラズマからの放射および温度の径方向分布 変化を測定し， $\mathrm{SF}_{6}$ ガスの混合の量的な影響をも検討して いる。ここでベース熱プラズマとしてArプラズマを用い ている理由は，Arが(1) プラズマの維持が容易なガスであ る，(2) 希ガスで反応性にそしく，混入ガスがプラズマに与 える影響を検討できる，ためである。このような測定によ り $\mathrm{SF}_{6}$ ガスが熱プラズマに与える影響を基礎実験的に容易 に検討できる。

さらに理論的アプローチとして, 圧力 $0.1 \mathrm{MPa} の \mathrm{Ar}-\mathrm{SF}_{6}$ 誘導プラズマを対象として局所熱平衡 (LTE) を仮定した二 次元数值熱流体解析モデルを構筑し， $\mathrm{SF}_{6}$ ガスを混入した Ar プラズマの温度分布を数值的に求めている。この結果と, 実験的に得られた結果とを比較，検討している。

2. 誘導熱ブラズマの発生維持機構とそのアーク消 弧特性解明への適用

図1はアークと誘導熱ブラズマの発生維持機構の概略図で ある。いずれも大気圧程度で維持され，ガス粒子の温度が 数干から数万Kと非常に高い「熱プラズマ」に属する(21)。 アークは通常，電極を有し，ア一ク軸方向に電流を流して 導電性を維持している。これに対し，誘導熱ブラズマはコ イルに高周波交番電流を流し，ト一千内に軸方向交番磁界 を発生させ，周回方向の交番電界を発生させる。これによ りプラズマ内に高周波電流を周回方向に流すことにより熱 プラズマを維持する。アークの場合にはアークプラズマ軸 上が最も電流密度が大きくなるが，誘導熱プラズマの場合 は軸上で電流密度は零であり，径方向のある位置で極大值 を取る。したがって，アークにおいては中心付近で温度極 大值が存在するのに対し，誘導熱ブラズマにおいては電流 路である中心と壁の間において温度の極大值が存在する。

$\mathrm{SF}_{6}$ ガスの強い消弧能力は，(1) 温度 $2000 \mathrm{~K}$ 付近におい

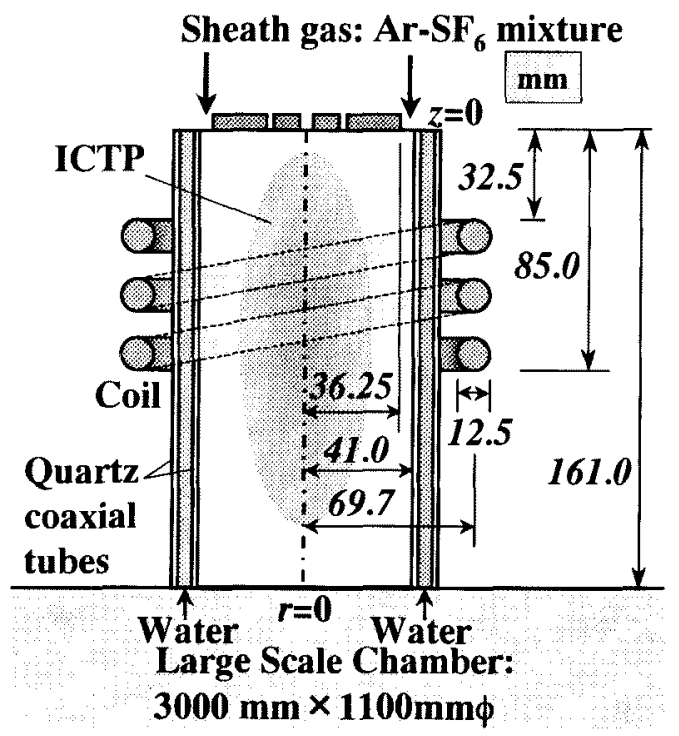

図2 プラズマトーチの概略図

Fig. 2. Schematic diagram of plasma torch.

て大きな熱伝導率を有するため，アークプラズマが径方向 に細く絞られてアークプラズマが細くなり過渡応答が速い， (2)F 原子など $\mathrm{SF}_{6}$ ガス分解フッ化物が大きな電子付着断面 積を有し，電子を移動度の小さい負イオンに変換する，ため とされている(16)。こ机らは定常 ICTP内においては，(1) によりICTPが径方向に収縮する，(2)により供試気体の混 合比を増加させると電子密度が減少し，ひいては電子温度 およびガス温度が低下して熱プラズマが消弧される，と予 想され，これらがガスの消弧能力の一判定材料となると考 えられる。

アークの消弧現象は基本的に過渡現象であり，一方，今 回導入する誘導熱ブラズマは通常定常現象である。しかし， 上述の判定基準により消弧性能を決める上記 (1)(2)の事項 を判断できるものと考えている。

3. 実験装置およびスペクトル観測システム

〈3・1〉プラズマトーチ罒2に，本実験において使用 した高周波誘導熱プラズマト一チの断面図を示す。ト一チ は石英管二重構造になっており, その内径は $82 \mathrm{~mm} \phi$, 外 径は $100 \mathrm{~mm} \phi$, 長さは $161 \mathrm{~mm}$ である。この内管と外管と の間に冷却水を下方向加ら旋回させて流寸ことによって石 英管壁をほぼ $300 \mathrm{~K}$ に保持している。石英管内部には，上 部からシースガスを管壁に沿って流し，ブラズマが管壁に 触れるのを防いでいる。トーチ下部には，3000 mm×1100 $m m \phi$ 大容量チャンバが取り付けてある。ガスとしてはAr あるいは Ar-SF 6 の混合ガスを用いている。表1に本実験に おける混合ガスの流量を示す。本実験においては，総流量 在 100 liters $/ \mathrm{min}\left(=1.67 \times 10^{-3} \mathrm{~m}^{3} / \mathrm{s}\right)$ 一定として, $\mathrm{SF}_{6}$ ガ スの混合比を流量比で $0.0,0.2,0.5,1.0$ および $2.0 \%$ の計 5 


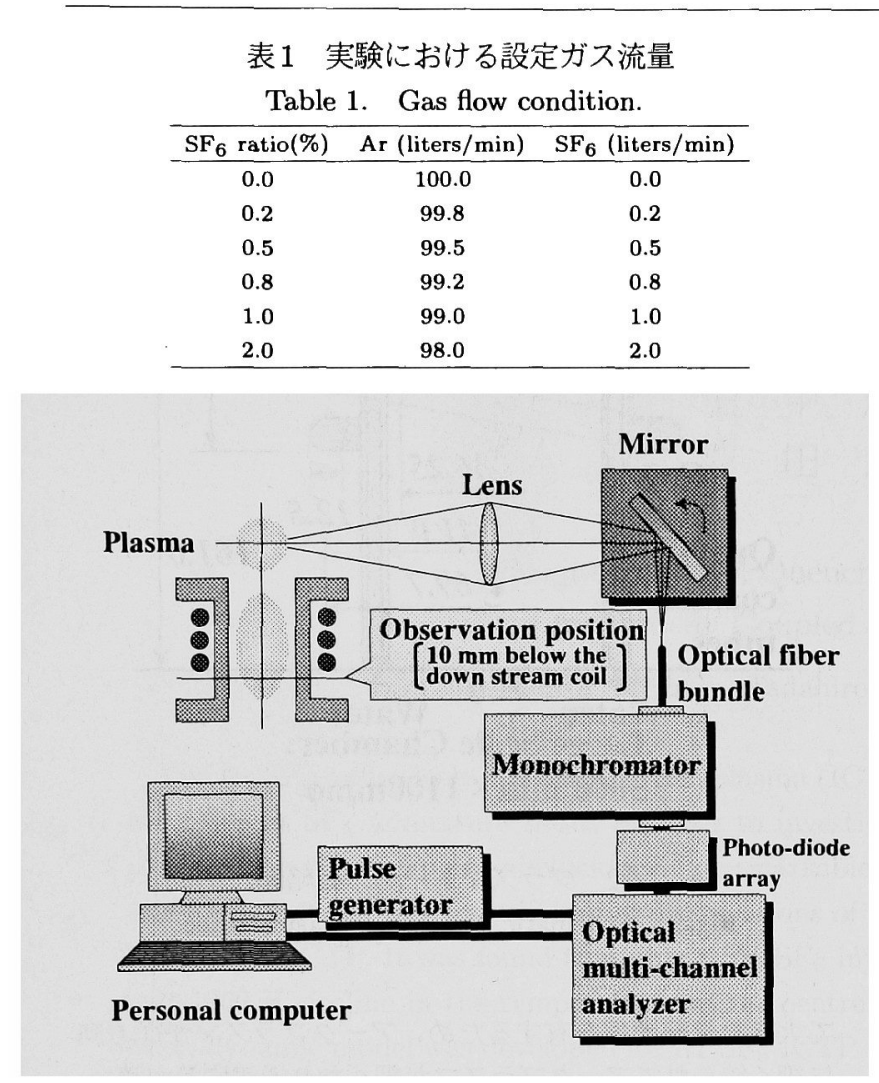

図3 スペクトル観測システム

Fig. 3. Spectroscopic observation system.

種類に設定している。石英管の外側には，管を取り巻くよ うに 3 ターンの誘導コイルが設置してある。このコイルに は真空管型の高周波発振回路が接続されており, $1.67 \mathrm{MHz}$ の高周波電流が流れる。これにより，管内に高周波電磁場 が発生しプラズマが点弧する。実験においては，いずれの $\mathrm{SF}_{6}$ ガス混合比においてもチャンバ内圧力をほぼ $0.1 \mathrm{MPa}$ に保っている。発振回路内の真空管プレート端子での入力 電力を $50 \mathrm{~kW}$ 一定としている。真空管は電力変換効率が約 $60 \%$ 悪いため, プラズマには $30 \mathrm{~kW}$ 程度が入力されて いる(20)。

〈3.2〉 スペクトル観測システム 四3に，スペクトル 観測システムを示す。実験においては, コイル下約 $10 \mathrm{~mm}$ の位置からの放射光を測定している。この位置から放射さ れた光は凸レンズおよび反射鏡を介して光ファイバ束の一 端に集光している。反射鏡にはステッピングモータが取り 付けてあり，モ一夕を回転させることにより，観測位置を プラズマの径方向に掃引することができる。光ファイバ束 の他端は分光器のスリット前面に固定してある。分光器の 出力焦点面には一次元マルチチャンネル検出器が搭載され ており, 波長域 $100 \mathrm{~nm}$ のスペクトル分布を一括測定でき る。本測定においては，Ar原子スペクトルが多く存在する $700 \pm 50 \mathrm{~nm}$ の範囲を対象としている。本システムの波長 分解能は約 $0.3 \mathrm{~nm}$ である。

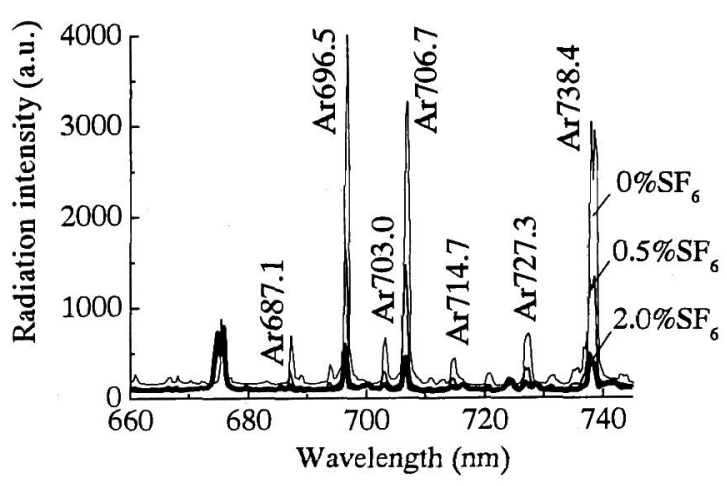

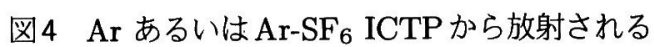
スペクトル

Fig. 4. Spectra emitted from $\mathrm{Ar}$ or $\mathrm{Ar}_{-} \mathrm{SF}_{6}$ ICTP.

\section{4. $\mathrm{SF}_{6}$ ガス混入による Ar ICTPへの影響}

$\langle 4 \cdot 1\rangle$ 放射強度 図 4 は, $100 \% \mathrm{Ar}, 99.5 \% \mathrm{Ar}-0.5 \% \mathrm{SF}_{6}$ および $98.0 \% \mathrm{Ar}-2.0 \% \mathrm{SF}_{6} \mathrm{ICTP}$ のコイル下 $10 \mathrm{~mm}$ のトー チ中心部で観測したスペクトル分布である。同図から，7本 のArスペクトルが確認できる。これらのスペクトルの放射 強度仿いずれも $\mathrm{SF}_{6}$ ガス混合比が大きくなると顕著に低下 している。例えば， $0.5 \% \mathrm{SF}_{6}$ ガスを加えるだけで，放射強 度はほぼ半分にまで減少する。図5は，7 本のスベクトルの 放射強度を，横軸を $\mathrm{SF}_{6}$ ガス混合比として示したものであ る。いずれのスペクトルの放射強度も $\mathrm{SF}_{6}$ ガス混合比が增 加すると，ほぼ同様に指数関数的に減少している。 $\mathrm{SF}_{6}$ 力゙ 不混合比を $3 \%$ 以上にすると ICTP が不安定になり, 維持が 難しくなることも確認している。

これらのスペクトルの放射強度は，それぞれの上準位励 起エネルギーに励起された粒子の数に比例している。これ らの励起エネルギー準位は準安定状態ではなく, 励起され ると数百 ns 程度で直ちに光を放出するため, ここでの放射 強度は励起過程に密接に関係している。また，本実験にお けるプラズマの圧力は大気圧と高いため, 励起過程は $\mathrm{Ar}$ と 電子との衝突が主原因と考えられる。このことから，放射 強度の大小は衝突する電子の運動エネルギーすなわち電子 温度の大小に密接に関係していると考えられる。実験では， 数\%程度の $\mathrm{SF}_{6}$ ガス混合によってでも放射強度が顕著に低 下しており，これは電子温度の低下を意味している。

比較のため, $\mathrm{N}_{2}$ を $3 \%$ まで混合させた場合についても同 様の実験を行った。図6は, $\mathrm{Ar}$ スペクトル放躬強度の $\mathrm{N}_{2}$ 混 合比依存性である。同図から, $\mathrm{N}_{2}$ を $3 \%$ 混合させた場合, こ れら 7 本のスペクトル放射強度はほとんど変化していない ことがわかる。したがって, 放躬強度の大きな減少は $\mathrm{SF}_{6}$ ガスの消弧性能の高さを示す一指標と考えられる。

次に，反射鏡に取り付けたステッピングモー夕を動作さ せることにより，スペクトルの径方向分布を測定した。図 7 は，測定されたスペクトル線のうち，例として波長 703.0 


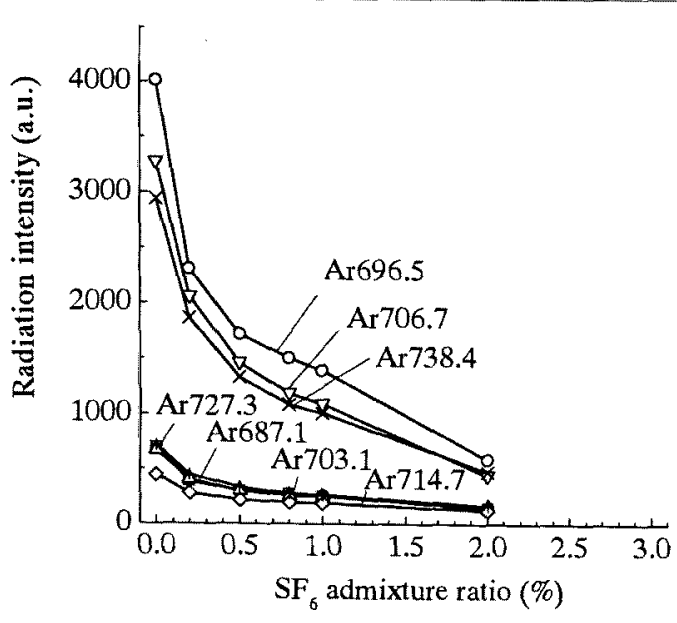

図5 放射強度のSF 6 ガス混合比依存性

Fig. 5. Dependence of radiation intensities of $\mathrm{Ar}$ lines on $\mathrm{SF}_{6}$ admixture ratio.

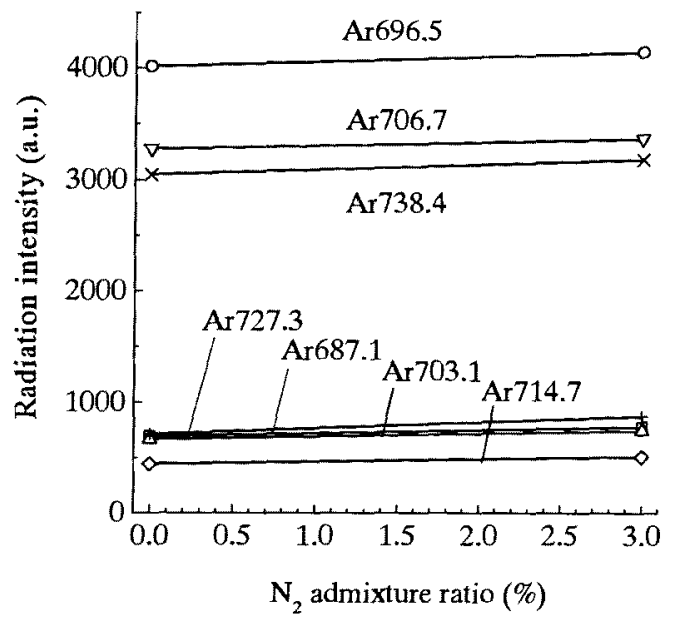

図6 放射強度の $\mathrm{N}_{2}$ ガス混合比依存性

Fig. 6. Dependence of radiation intensities of $\mathrm{Ar}$ lines on $\mathrm{N}_{2}$ admixture ratio.

$\mathrm{nm}$ における $\mathrm{Ar}$ スペクトルの放射強度の径方向分布を示し ている。横軸 $0 \mathrm{~mm}$ の位置はプラズマ軸上を示しておう、 $41 \mathrm{~mm}$ の位置が管内壁を示している。測定は径方向に 32 点とっている。同図から, $\mathrm{SF}_{6}$ ガスを $0.2 \%$ 加えるだけで $\mathrm{Ar}$ スペクトル放射強度が径方向全体で極端に小さくなり，フ ラズマ中心では約 $2 / 3$ になる。このため，発光空間が径方 向に収縮した様子となっている。別途， $\mathrm{N}_{2}$ を混合させた Ar ICTPからのAr スペクトル放射強度を観測したが，放 射強度の径方向分布はほとんど低下せず，そのままの形が 維持された。プラズマ空間の径方向への收縮はプラズマ過 渡特性とも関わっており ${ }^{(6)}$ ，ICTPを使用した本手法にお いても収縮現象を捉えられることを確認てきた。

$\langle 4 \cdot 2\rangle$ 温 度 局所熱平衡(LTE) が成立する場合, 相異なる 2 本の同種粒子からのスペクトル線の放射強度比 から相対強度法により温度を算出できる。誘導熱プラズマ

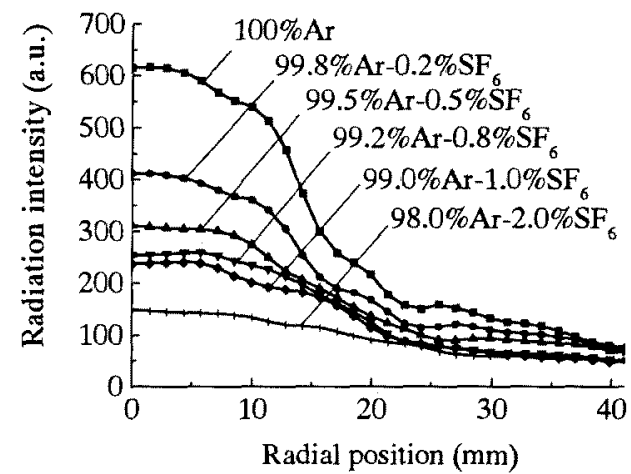

四7 コイル下 $10 \mathrm{~mm}$ 位置におけるArスペクト 儿放射強度の径方向分布

Fig. 7. Radial distribution of radiation intensity of Ar lines at $10 \mathrm{~mm}$ below the coil end for different $\mathrm{SF}_{6}$ admixture ratios.

\section{表2 原子定数}

Table 2. Atomic constants.

\begin{tabular}{cccc}
\hline$\lambda(\mathrm{nm})$ & $g$ & $A\left(\mathrm{~s}^{-1}\right)$ & $E\left(\mathrm{~cm}^{-1}\right)$ \\
\hline 703.0 & 5 & $0.0278 \times 10^{8}$ & 119683 \\
714.7 & 3 & $0.0065 \times 10^{8}$ & 107132 \\
\hline
\end{tabular}

では，プラズマ中心付近においては電界強度が極妙て小さ いためほぼLTEが成立し，壁付近においては電子温度がガ ス温度より高くなり，いわ省熱的非平衡性が存在すると 考えられる ${ }^{(26)}$ 。本実験条件においては，プラズマの圧力が 大気圧と比較的大きいことから, 中心から径方向 $20 \mathrm{~mm}$ 程 度までの領域でLTEを仮定 ${ }^{(26)}$ して温度を求めた。ここで,

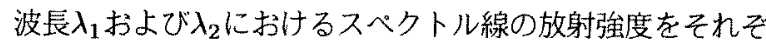
れ $I_{1}$ および $I_{2}$ とすると, 温度 $T$ は次式で求められる ${ }^{(22) 。 ~}$

$$
T=\frac{E_{1}-E_{2}}{k\left(\ln \frac{g_{2} A_{2} \lambda_{1}}{g_{1} A_{1} \lambda_{2}}-\ln \frac{I_{1}}{I_{2}}\right)}
$$

ここで, $k$ : Boltzmann定数， $g$ :上準位の縮退度， $E$ :上準 位エネルギー，A: 遷移確率である。本算出においては，波 長703.0および714.7 nmにおけるAr スペクトルを選んだ。 これらのスベクトル線の原子定数を表 $2^{(23)}$ に示す。これら のスベクトル線を選んだ理由は，上準位エネルギーレベル の差 $E_{1}-E_{2}$ が $1.51 \mathrm{eV}$ と比較的大きく，温度を精度よく 算定できると考えられるためである ${ }^{(22) 。 ま た ， こ れ ら の 二 ~}$ 本のスペクトルの二線強度比法で得ら机る温度は，7本の 波長 687.1, 696.5, 703.0, 706.7, 714.7, 727.3 および 738.4 nmにおけるArスペクトルを用いたBoltzmann plot法に より得られる温度と同程度であることも確認している。こ こで得られる温度は上述のエネルギーレベル間の $\mathrm{Ar}$ 励起温 度である。これは，電子温度に比較的近いとされ，今回の ように高気圧プラズマでは本算定範囲でガス温度にも近い と考えられる。

図7の放射強度分布は，径方向に積算されたものである。 このため, Abel 逆変換 ${ }^{(24)}$ を施して真の放射強度分布を求 


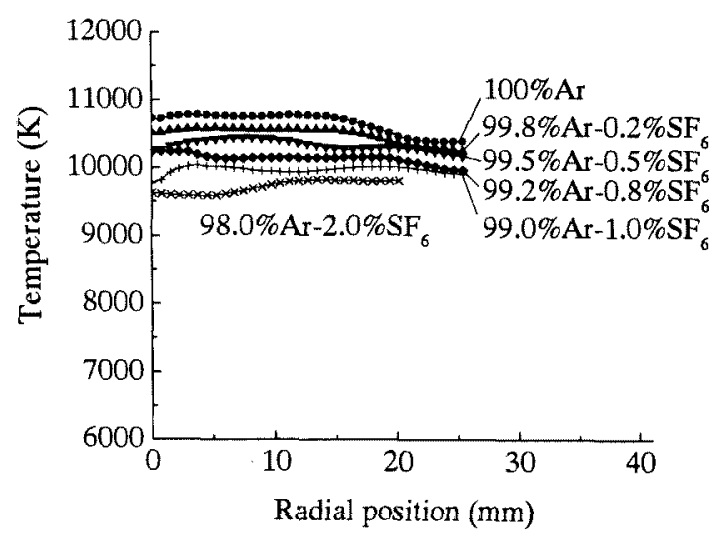

図8 Arおよび Ar-SF 6 ICTP の温度径方向分布

Fig. 8. Radial temperature distribution of $\mathrm{Ar}$ or $\mathrm{Ar}^{-\mathrm{SF}_{6}}$ ICTP.

めて, 温度を式 $(1)$ により算出した。四8は, 様々な $\mathrm{SF}_{6} カ ゙$ ス混合比におけるAr-SF ${ }_{6}$ ICTPの温度の径方向分布であ る。同図からいずれの混合比においてもプラズマ温度分布は ほぼ平坦で $10000 \mathrm{~K}$ 前後であり， $\mathrm{SF}_{6}$ ガス混合比を増加さ せると温度も次第に低下している。 $\mathrm{SF}_{6}$ ガス混合比が $2 \%$ は, $100 \% \mathrm{Ar}$ の温度よりも $1000 \mathrm{~K}$ 程度低下している。この ように， $\mathrm{SF}_{6}$ ガスを微量混入させるだけで，観測位置におけ る温度が低下することを実験的に見いだした。これは $\mathrm{SF}_{6}$ ガスの強い消弧性能と関わっているものと考えられる。

\section{5. $\mathrm{Ar}-\mathrm{SF}_{6}$ ICTP のモデリング}

前節までに得られた放射および温度低下を説明するため に，本節では $\mathrm{Ar}^{-\mathrm{SF}_{6}}$ ICTPのモデリングを行う。

$\langle 5 \cdot 1\rangle$ 支配方程式 誘導熱プラズマが, (i) 定常状態で ある, (ii) 局所熱平衡状態にある, (iii) 光学的に薄い, (iv) 流れは層流であって乱流の効果が無視できる，と仮定でき るとき, 誘導熱プラズマは次の支配方程式に從う ${ }^{(25)}$ 。

質量保存式:

$$
\frac{\partial(\rho u)}{\partial z}+\frac{1}{r} \frac{\partial(r \rho v)}{\partial r}=0
$$

運動量保存式:

$$
\begin{aligned}
& \rho u \frac{\partial u}{\partial z}+\rho v \frac{\partial u}{\partial r} \\
& =-\frac{\partial p}{\partial z}+2 \frac{\partial}{\partial z}\left(\eta \frac{\partial u}{\partial z}\right) \\
& +\frac{1}{r} \frac{\partial}{\partial r}\left[\eta r\left(\frac{\partial u}{\partial r}+\frac{\partial v}{\partial z}\right)\right]+\mu_{0} \sigma \Re\left[\dot{E}_{\theta} \dot{H}_{r}^{*}\right] \ldots \ldots \\
& \rho u \frac{\partial v}{\partial z}+\rho v \frac{\partial v}{\partial r} \\
& =-\frac{\partial p}{\partial r}+\frac{\partial}{\partial z}\left[\eta\left(\frac{\partial v}{\partial z}+\frac{\partial u}{\partial r}\right)\right] \\
& +\frac{2}{r} \frac{\partial}{\partial r}\left(\eta r \frac{\partial v}{\partial r}\right)-2 \eta \frac{v}{r^{2}}+\mu_{0} \sigma \Re\left[\dot{E}_{\theta} \dot{H}_{z}^{*}\right] \ldots .
\end{aligned}
$$

エネルギー保存式:

$$
\begin{aligned}
& \rho u \frac{\partial h}{\partial z}+\rho v \frac{\partial h}{\partial r} \\
& =\frac{\partial}{\partial z}\left(\frac{\lambda}{C_{p}} \frac{\partial h}{\partial z}\right)+\frac{1}{r} \frac{\partial}{\partial r}\left(r \frac{\lambda}{C_{p}} \frac{\partial h}{\partial r}\right) \\
& +\sigma\left|\dot{E}_{\theta}\right|^{2}-P_{\mathrm{rad}} \ldots \ldots \ldots \ldots \ldots
\end{aligned}
$$

ベクトルポテンシャルに関する Maxwell 方程式:

$$
\begin{aligned}
& \frac{\partial^{2} \dot{A}_{\theta}}{\partial z^{2}}+\frac{1}{r} \frac{\partial}{\partial r}\left(r \frac{\partial \dot{A}_{\theta}}{\partial r}\right)-\frac{\dot{A}_{\theta}}{r^{2}}=j \mu_{0} \sigma \omega \dot{A}_{\theta} \ldots \ldots \\
& \dot{H}_{z}=\frac{1}{\mu_{0} r} \frac{\partial}{\partial r}\left(r \dot{A}_{\theta}\right), \quad \dot{H}_{r}=-\frac{1}{\mu_{0}} \frac{\partial \dot{A}_{\theta}}{\partial z} \ldots \ldots \\
& \dot{E}_{\theta}=-j \omega \dot{A}_{\theta} \ldots \ldots \ldots \ldots \ldots \ldots \ldots \ldots \ldots
\end{aligned}
$$

ここで $r$ ：径方向位置 $(\mathrm{m}), z$ ：軸方向位置 $(\mathrm{m}), u$ : 軸 方向の流速 $(\mathrm{m} / \mathrm{s}), v$ : 径方向の流速 $(\mathrm{m} / \mathrm{s}), \rho$ : 質量密度 $\left(\mathrm{kg} / \mathrm{m}^{3}\right), p$ : 圧力 $(\mathrm{Pa}), \eta$ : 層流粘性係数 $(\mathrm{Pa} \cdot \mathrm{s}), h$ : エン夕 ルピー $(\mathrm{J} / \mathrm{kg}), \lambda$ : 層流熱伝導率 $(\mathrm{W} / \mathrm{m} / \mathrm{K}), C_{\mathrm{p}}$ : 定圧比熱 $(\mathrm{J} / \mathrm{kg} / \mathrm{K}), \sigma:$ 導電率 $(\mathrm{S} / \mathrm{m}), P_{\mathrm{rad}}$ : 放射損失 $\left(\mathrm{W} / \mathrm{m}^{3}\right), \mu_{0}$ : 真空中の透磁率 $\left(=4 \pi \times 10^{-7} \mathrm{~F} / \mathrm{m}\right), \dot{A}_{\theta}$ : ベクトルボテン シャル, $\omega$ : コイル電流の角周波数 $(\mathrm{rad} / \mathrm{s}), \dot{E}_{\theta}$ : 電界強度 $(\mathrm{V} / \mathrm{m}), \dot{H}_{z}, \dot{H}_{r}$ : 軸および径方向の磁界強度 $(\mathrm{A} / \mathrm{m}), j:$ 虚 数 $\left(j^{2}=-1\right)$. ベクトルボテンシャル $\vec{A}(r, z, t)$ は周回方向 成分のみ存在し, $\vec{A}(r, z, t)=\left(0, \dot{A}_{\theta} \exp (j \omega t), 0\right)$ と書ける。 ここで，ドットはフェーザで，例えば $\dot{A}_{\theta}=A_{\theta R}+j A_{\theta I}$ のように実部と虚部とを持ち，その大きさは実効值である。

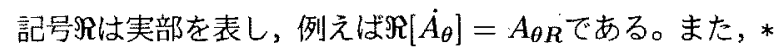
は共役複素数を表している。

$\langle 5 \cdot 2\rangle$ 解析空間，境界条件および計算手法 解析空間 は図 1 に示す長さ $161 \mathrm{~mm}$, 径 $41 \mathrm{~mm}$ の円柱断面の半面で ある。この空間を軸方向に 85 , 径方向に 42 のグリッドに非 等分割している。このグリッドに対して式 (2)-(6) をコント ロールボリューム法により差分化している ${ }^{(29)}$ 。境界条件と しては，壁温度を管壁における熱伝達を考虑して与えてい る。壁位置における流速は $0 \mathrm{~m} / \mathrm{s}$ に固定し, いわゆる滑り なし条件としている。壁位置におけるべクトルポテンシャ ルについては，コイル電流とプラズマ内に流れる渦電流と を考慮して計算している。プラズマ中心軸においては，円 柱対称条件を適用している。 $z=161 \mathrm{~mm}$ 位置においては, ガスおよび熱流束は自由流出としている。

$\mathrm{Ar}_{-} \mathrm{SF}_{6}$ 混合ガスの熱力学・翰送特性については, $0.1 \mathrm{MPa}$ における熱平衡值を Chapman-Enskog 法の一次近似により

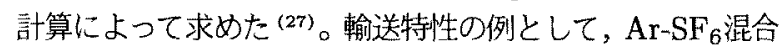
ガスプラズマの熱伝導率を図 9 に示す。図 9 加ら, $100 \% \mathrm{SF}_{6}$ には温度 1800,2200 および $2800 \mathrm{~K}$ に特幑的な極大が存在 することがわかる。これらは，それぞれ $\mathrm{SF}_{6}, \mathrm{SF}_{4}$ および $\mathrm{SF}_{2}$ の解離にともなう等価的な熱伝導率の増加である ${ }^{(28)}$ 。 $\mathrm{SF}_{6}$ ガス混合比を上昇するとこれらの極大が顕著にみられ るようになる。罒10は Ar-SF 6 混合ガスプラズマの放射パ ワ一の温度依存性である。放射パワーの計算においては， 共鳴線を除く線スベクトル放射と連続スペクトル放射とを 


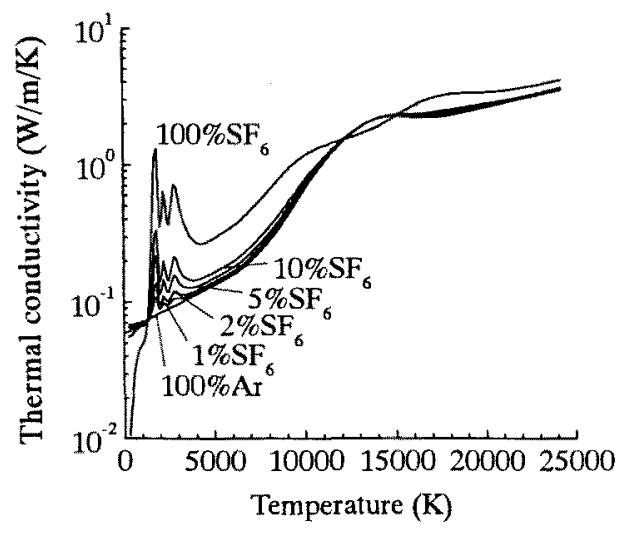

四9 大気圧 $\mathrm{Ar}-\mathrm{SF}_{6}$ 混合ガスの熱伝導率の温度依 存性

Fig. 9. Thermal conductivity of Ar-SF 6 gas mixtures at atmospheric pressure for different $\mathrm{SF}_{6}$ admixture ratios.

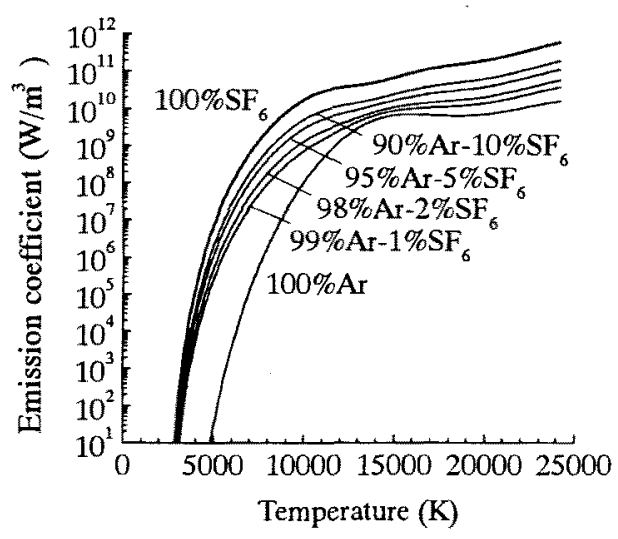

図 10 大気压 $\mathrm{Ar}-\mathrm{SF}_{6}$ 混合ガスの放射係数の温度 依存性

Fig. 10. Radiation power of $\mathrm{Ar}_{-} \mathrm{SF}_{6}$ gas mixtures at atmospheric pressure for different $\mathrm{SF}_{6}$ admixture ratios.

考慮した。近年，吸収を考慮したプラズマからの正味の放 射係数の算出がなされている(15)。しかし，これらはプラス マを均一円筒形と仮定した計算結果であり， $\mathrm{Ar}_{-} \mathrm{SF}_{6}$ 混合力 スに对するものはほとんどない。このため，本計算におい ては簡単化のため，昅収については考慮していない。この 結果，ここで計算した放射係数は実際にブラズマから放出 されるパワーより大きくなり，後の温度の計算結果も実際 より低く見積もられることになる。図10において，放射パ ワーは $\mathrm{SF}_{6}$ ガスを混入させると特に温度 $10000 \mathrm{~K}$ 以下で大 きく増加している。これは温度 $10000 \mathrm{~K}$ 以下において波長 $200 \mathrm{~nm}$ 以下におけるS線スペクトル放射が特に大きいた めである。

導出した差分方程式については，ブラズマへの入力電力 $30 \mathrm{~kW}$ 一定条件のもと, PatankarのSIMPLER 法 ${ }^{(29) に よ ~}$ り収束解老得ている。
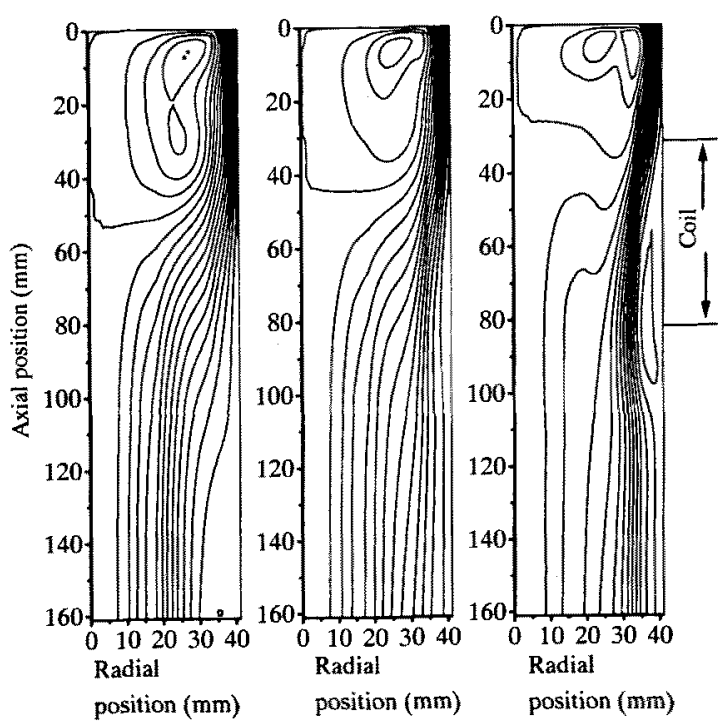

$\begin{array}{ll}\text { (a) } 100 \% \mathrm{Ar} & \text { (b) } 99.5 \% \mathrm{Ar}-0.5 \% \mathrm{SF}_{6} \text { (c) } 98.0 \% \mathrm{Ar}-2.0 \% \mathrm{SF}_{6}\end{array}$

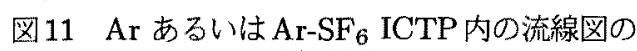
計算結果

Fig. 11. Stream lines in $\mathrm{Ar}$ or $\mathrm{Ar}-\mathrm{SF}_{6}$ ICTP

\section{6. 計算結果}

図11は，それそれれ100\% Ar, 99.5\% Ar-0.5\% $\mathrm{SF}_{6}$ および 98.0\% Ar-2.0\% $\mathrm{SF}_{6}$ ICTPにおける流線を示したものであ る。流線の接線方向にガスは流れ，流線と流線との間には 同流量が流れる。同図から，管壁に浻って上部から流した ガスの一部が，ICTPの上部に渦を形成していることがわ かる。これはコイル中心 $z=60 \mathrm{~mm}$ 付近において，プラズ マにLorentz 力 $\Re\left[\dot{E}_{\theta} \dot{H}_{z}^{*}\right]$ が働き，径方向の内側方向へガス が加速されるためである。 $\mathrm{SF}_{6}$ ガス混合比を増加させると， この渦は次第に小さくなる。 $\mathrm{SF}_{6}$ ガス混合比が $2.0 \%$ になる と，z=60 $\mathrm{mm}$ の管壁付近において新たな瀜が発生してい る。これは， $\mathrm{SF}_{6}$ ガス混合比が大さくなるとブラズマが佳 方向に収縮し，それを補うようにガスが導入させるためで ある。

図12(a),(b) および (c) は，それぞれ100\%Ar, 99.5\%Ar$0.5 \% \mathrm{SF}_{6}$ および $98.0 \% \mathrm{Ar}-2.0 \% \mathrm{SF}_{6}$ ICTPにおける温度分 布を等温線表示したものである。等温線は $1000 \mathrm{~K}$ 毎に描 いてある。同図から，100\%Ar ICTPにおいては，広い空 間にわたって温度 $9000 \mathrm{~K}$ 以上の高温領域が存在する。それ が, $\mathrm{SF}_{6}$ ガスの混合比を $0.5 \%$ とすると, 温度 $9000 \mathrm{~K}$ 以下 の領域は断面積比で $1 / 4$ 程度にまで小さくなっている。ま た，高温領域は径方向に縮まって中心付近に存在し，管壁付 近には $1000 \mathrm{~K}$ 以下の低温域が形成されている。 $\mathrm{SF}_{6}$ ガス混 合比を $2.0 \%$ に增すと，この傾向はますます顕著になり，管 壁から約 $10 \mathrm{~mm}$ の幅の領域は $1000 \mathrm{~K}$ 以下の低温域となっ ている。

次に，この温度低下がどのような物理機構により生じて いるのかを調へるために各点に拈けるエネルギーバランス 


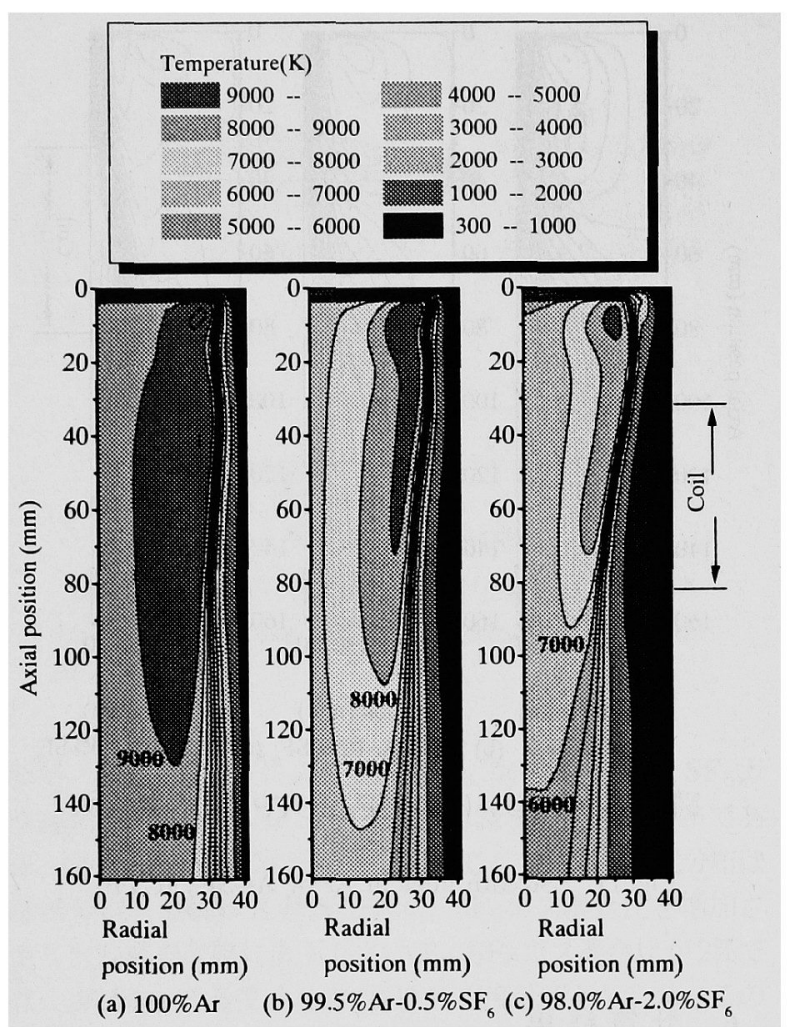

図 12 Ar あるいは $\mathrm{Ar-SF}_{6}$ ICTP 内の温度分布
の計算結果

Fig. 12. Isothermal contours for $\mathrm{Ar}$ or $\mathrm{Ar}_{-} \mathrm{SF}_{6}$ ICTP.

を計算した。具体的には式(5)の各項をそれぞれのコント ロールボリュームで積分して求めた。図 13 (a)および(b) はそれぞれ $100 \% \mathrm{Ar}$ および $98 \% \mathrm{Ar}-2 \% \mathrm{SF}_{6}$ ICTP のコイル 中心位置 $z=60 \mathrm{~mm}$ でのエネルギーバランスの径方向分布 を示している。図13の $100 \% \mathrm{Ar}$ の場合については, 入力電 力は $r=28 \mathrm{~mm}$ 付近に極大をもっており,この付近のガス の温度を上昇させている。温度が高くなったガスは径方向 対流によりプラズマ中心付近に運ばれて，軸方向対流によ り熱流としてトーチ下側方向に運ばれていく。損失機構と して，支配的な要素は径および軸方向対流と放射損失であ る。一方，図 13 の $98 \% \mathrm{Ar}-2 \% \mathrm{SF}_{6}$ の場合には，温度 $2000 \mathrm{~K}$ 付近において熱伝導率が大きくなるためプラズマ温度分布 が径方向に縮まり，入力電力も $r=18 \mathrm{~mm}$ 付近に極大を もっている。また, $\mathrm{SF}_{6}$ ガスの混入により特に紫外域にお けるS 線スペクトル放射による放射損失が増し，損失機構 の重要な要素となっている。これらは通常吸収も大きいが, これらからの放射を考慮しないと温度の低下は見られない。 このことから，紫外域におけるS 線スペクトル放射による 放射損失の要素となっていると考えている。

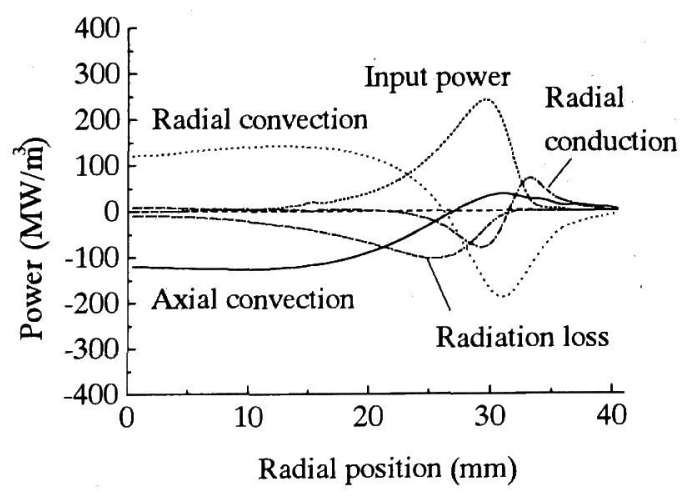

(a) $100 \% \mathrm{Ar}$.

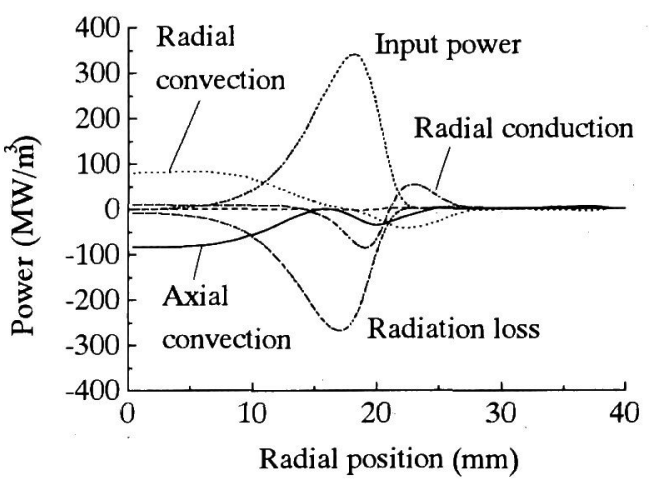

(b) $98 \% \mathrm{Ar}-2 \% \mathrm{SF}_{6}$.

図13 $\mathrm{Ar}$ あるいは $\mathrm{Ar}-\mathrm{SF}_{6}$ ICTP内の $z=60 \mathrm{~mm}$ 位置におけるエネルギー収支

Fig. 13. Energy balance in $\mathrm{Ar}$ or $\mathrm{Ar}-\mathrm{SF}_{6}$ ICTP at $z=60 \mathrm{~mm}$.

\section{7. 計算結果と実測值との比較}

実測結果と計算結果とを比較するために，計算結果から コイル下 $10 \mathrm{~mm}$ の位置における温度の径方向分布を求め た。図14に，その結果を示す。 $\mathrm{SF}_{6}$ ガス混合比がパラメー 夕となっている。同図から，Ar ICTP の温度径方向分布は $\mathrm{SF}_{6}$ ガス混合比が増すに従い温度が低下し, かつプラズマ の中心軸に近づくように高温領域が移動する。また，温度 $2000 \mathrm{~K}$ 付近において温度勾配 $\frac{\partial T}{\partial r}$ がその前後で変化してい る。これらは，温度 $10000 \mathrm{~K}$ 以下の放射損失が大きくなる ことと, 温度 $2000 \mathrm{~K}$ 付近における熱伝導率が増加するた めである。この温度分布の傾向は, 図8の実験結果からも 得られており, $\mathrm{SF}_{6}$ ガス混入による温度低下現象を定性的 に説明できたと考えられる。しかしながら，実測結果に比 較して計算結果の方が温度が低くなっている。これは，今 回の計算においてはプラズマが光学的に薄いと仮定して吸 収を考虑に入れていないため，見積もった放射損失が実際 より大きかったためと考えられる。

8. 結 論

本論文においては，誘導結合形熱プラズマ(ICTP) を用 


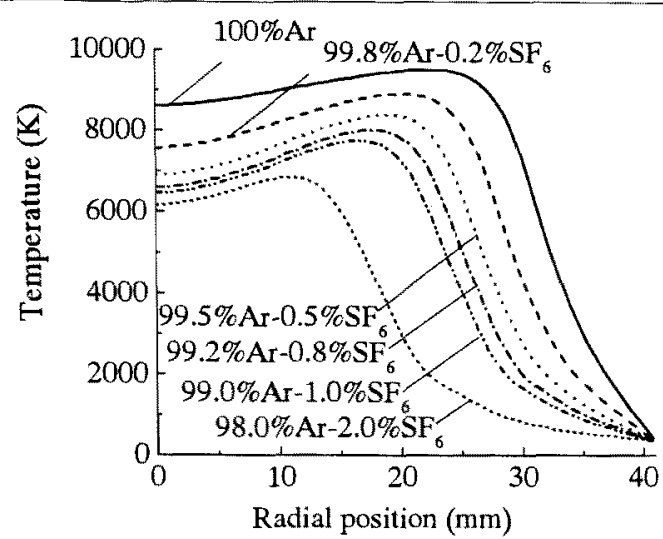

図14コイル下 $10 \mathrm{~mm}$ 位置における温度の径方 向分布の計算結果

Fig. 14. Calculated radial temperature distribution of $\mathrm{Ar}$ or $\mathrm{Ar}_{-} \mathrm{SF}_{6} \mathrm{ICTP}$ at $10 \mathrm{~mm}$ below the coil end.

いて，消弧媒体 $\mathrm{SF}_{6}$ ガスが熱プラズマに与える影響を検討 した。入力電力 $50 \mathrm{~kW}$, 圧力 $0.1 \mathrm{MPa}$ 高出力・高気圧 の $\mathrm{Ar}$ 誘導熱プラズマを点弧し，そこに $\mathrm{SF}_{6}$ ガスを $0.0,0.2$, $0.5,1.0$ および $2.0 \%$ と混入した場合のプラズマからの放射 および温度の径方向分布変化を実験的に求めた。その結果， $\mathrm{SF}_{6}$ ガスを数\%混入させるだけで放射強度, 温度ともに大 きく低下することが明らかとなった。放射強度分布は径方 向に細くなることも確認できた。これらの傾向は $\mathrm{N}_{2}$ などを 混合させた場合には晃られず， $\mathrm{SF}_{6}$ ガスの高い消弧性能と 関連していると考えられ，誘導熱プラズマ発生装置による 遮断器用消弧媒体の性能評価試験法としての可能性を見い だせた。さらに理論的アプローチとして, 圧力0.1MPaの $\mathrm{Ar}-\mathrm{SF}_{6}$ 誘導ブラズマを対象として局所熱平衡(LTE) を仮 定した二次元数值熱流体解析を行い， $\mathrm{SF}_{6}$ ガスを混入した Ar プラズマの温度分布を数值的に求めた。この結果により, 定性的に，実験的に得られた温度低下現象を説明できたと 考えられる。

\section{9. 謝辞}

本研究の一部は，新エネルギー・産業技街総合開発機構 (NEDO) からの受託により，新規産業創造型提案公募事業 の一環として実施したものである。

本実験にあたり，大容量誘導熱プラズマ装置を使用させ て頂いた（株）三菱重工業長崎研究所に感謝致します。実 験にご協力頂いた畑澤重則君 (現 (株) 関西電力), 高橋正文 君 (現 (株) 東京電力)に感謝致します。

(平成 12 年 7 月 27 日受付, 平成 12 年 11 月 24 日再受付)

$$
\text { 文献 }
$$

(1) H.M.Ryan and G.R.Jones: "SF6 switchgear", ch.2, 1989, Peter Pregrinus Lid., London.

(2) 家田:「高電压工学」, p .119，1981，才一社

（3）黑田: 「COP3 京都議定書と我が国の土ネルギ一政策」，電学誌， 118 , pp.697-700, 1998
(4) K.H.Yoon and H.E.Spindle: "A study of the dynamic response of arcs in various gases", AIEE, 1634-1642, 1959.

(5) V.G.Frind: "Über das Abklingen von Lichtbögen. I Theoretische Uberlegungen", Z. angewandte Physik, 5 231-237, 1960.

(6) V.G.Frind: "Über das Abklingen von Lichtbögen. II Prüfung der Theorie an experimentallen Untersuchungen", $Z$. angewandte Physik, 11 515-521, 1960

(7) A.Lee: "Interruption capability of gases and gas mixtures in a puffer-type interrupter", IEEE Trans. on Plasma Sci. , PS-8, 362-367, 1960

（8）宮屯，鎌谷:「吹付形恶楽器の電流零点近傍における現象（主として 時定数に简するもの)」, 電学詡 $\mathrm{B}, \mathrm{85}, 115-124,1965$.

(9) R.D.Garzon: "The effect of $\mathrm{SF}_{6}-\mathrm{N} 2$ mixture upon the recovery voltage capability of a synchronous interrupter", IEEE Trans. on Power Appar. ES Sys., PAS-95, 140-144, 1976.

(10) D.M.Grant, J.F.Perkins, L.C.Campbell, O.E.Ibrahim and O.Farish: "Comparative interruption studies of gas-blasted arcs in $\mathrm{SF}_{6}-\mathrm{N}_{2}$ and $\mathrm{SF}_{6}-\mathrm{He}$ mixtures", Proc. on Int. Conf. on Cas Discharges and Their Applications, 48-51,-.

(11) A.Gleizes, M.Razafinimanana and S.Vacquie: "Transport coefficients in arc plasma of $\mathrm{SF}_{6}-\mathrm{N}_{2}$ mixtures", J.Appl.Phys., 54, $3777-3787,1983$.

（12）筑紫，中川!，平沢，吉岡：「潍合力又を用いたバッファ式力又遮断

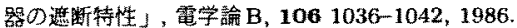

(13) A.Gleizes, M.Razafinimanana and S.Vacquie: "Calculation of Thermodynamic properties and transport coefficients for $\mathrm{SF}_{6} / \mathrm{N}_{2}$ mixtures in temperature range $1000-30000 \mathrm{~K}$ ", Plasma Chem. Plasma Process., 6, 65-78, 1986.

(14) A.Gleizes, I.Sakalis, M.Razafinimanana and S.Vacquie: "Decay of wall stabilized arcs in $\mathrm{SF}_{6}{ }^{-N_{2}}$ mixtures", J.Appl.Phys., $61,510-518,1987$

(15) A.Gleizes, B.Rahmani, J.J.Gonzalez and B.Liani: "Calculation of net emission coefficient in $\mathrm{N}_{2}, \mathrm{SF}_{6}$ and $S \mathrm{SF}_{6}-\mathrm{N}_{2}$ arc plasmas", J.Phys.D.Appl.Phys., 24, 1300-1309, 1991.

(16) B.Chervy, H.Riad and A.Gleizes: "Calculation of the interruption capability of $\mathrm{SF}_{6}-\mathrm{CF}_{4}$ and $\mathrm{SF}_{6}-\mathrm{C}_{2} \mathrm{~F}_{6}$ mixtures $-\mathrm{Part}$ I:Plasma Properties", IEEE Trans. on Plasma Sci., 24, 198$209,1996$.

(17) B.Chervy, J.J.Gonzalez and A.Gleizes: "Calculation of the interruption capability of $\mathrm{SF}_{6}-\mathrm{CF}_{4}$ and $\mathrm{SF}_{6}-\mathrm{C}_{2} \mathrm{~F}_{6}$ mixtures Part II:Arc Decay Modeling", IEEE Trans. on Plasma Sci., 24, 210-217, 1996.

(18) Y.Tanaka, K.C.Paul and T.Sakuta: "Thermodynamic and transport properties of $\mathrm{N}_{2} / \mathrm{O}_{2}$ mixtures at different admixture ratios", T.IEE of Japan, 120-B, 24-30, 2000.

(19) M.Razafinimanana, M.Bouaziz, B.Chervy, A.Gleizes, J.J. Gonzalez and S.Vaquie: "Influence of copper vapours on the characteristics of an $\mathrm{SF}_{6}$ arc", Proc. 11th Int. Conf. on Gas Discharges and Their Applications, Vol.I, pp.66-69, 1995.

(20) G.J.Cliteur，鉿木，K.C.Paul，作田:「Ar高周波被迸プラズマを

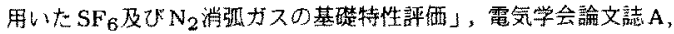
119-A, 482-489, 1999.

(21) M.1.Boulos, P.Fauchais and E.Pfender: Thermal Plasmas Fundamentals and Applications Vol.I, ch.1,1994, Plenum Press, New York.

(22) F.Cabannes and J.Chapelle: Reactions under Plasme Conditions, Vol.1, ch.7, ed. Venugopalan, 1971, Wiley. Interscience, New York.

(23) W.L.Wiese, M.W.Smith and B.M.Glennon: Atomic Transition Probabilities, Vol.II, 1969, NBS, Washington DC.

(24) A.Montaser and D.W.Golightly: Inductively Coupled Plasmas in Analytical Atomic Spectrometry, Second Edition, pp.383-384, 1992, VCH Publishers, Inc, New York.

(25) J.Mostaghimi and M.I.Boulos: "Two-dimensional electro magnetic field effects in induction plasma modelling", Plasme Chem. Plasma Process., 9, 25-44, 1989.

(26) J.Mostaghimi and M.I.Boulos; "A Two-temperature model of the inductively coupled r.f. plasma", $\boldsymbol{J}$. Appl. Phys., 61, $1753-1760,1987$

(27) J.M.Yos: "Transport properties of nitrogen, hydrogen, oxygen, and air to $30000 \mathrm{~K}$ ", Research and Advanced Devel opment Division AVCO Corporation, Massachusetts, 1967, Amendments to AVCO RAD-TM-63-7.

(28) B.Chervy, A.Gleizes and M.Razafinimanana: "Thermody namic properties and transport coefficients in $\mathrm{SF}_{6}-\mathrm{Cu}$ mix tures at temperatures of $300-30000 \mathrm{~K}$ and pressures of $0.1-1$ 
MPa", J. Phys. D: Appl. Phys., 27, 1193-1296, 1994.

(29) S.V.Patankar: Numerical Heat Transfer and Fluid Flow, 1980, Hemisphere Publishing Corp., New York

田中康 規 (正員) 1970 年生。1998 年 3 月名古屋大学大学 院工学研究科博士課程後期課程修了。同年 4 月金 沢大学工学部助手。工学博士。主として, 大電流 アーク遮断現象の解明, 熱プラズマ診断, 応用に 関する研究に従事。

作 田忠裕 (正員) 1950 年生。1980 年 3 月名古屋大学大学 院工学研究科博士課程後期課程修了。同年 4 月同 大学工学部助手。1 1988 年金沢大学工学部助教授, 1990 年同大学教授。工学博士。主として高気圧熱 プラズマ・アーク診断, 応用に関する研究に従事。 応用物理学会, IEEE会貝。 